\title{
Os Sete Pecados
}

Um manuscrito mal elaborado pode ser fonte de incompreensão, perplexidade, até mesmo de hostilidade da parte do leitor que, ao tomar conhecimento do título, deixou despertar seu interesse pelo mesmo. Pior do que a perplexidade, o não entendimento do conteúdo ou do que a própia hostilidade é o indício de suspeita que o que se apresenta não passa de um mau produto da imaginação criativa do autor, ou dos autores. Não que o homem da ciência não deva dar asas à criatividade, ou deva ser despojado de imaginação intuitiva. Simplesmente, a criatividade científica deve ser consistente com o que já se conhece a respeito, com a compreensão da natureza do que se estudou e com a necessidade de uma informação precisa, sem qualquer margem de dúvida. De posse desta atitude deve o autor preparar um relato dos achados com tal correção, que possa ser assimilado pelos leitores interessados. Relato simples, elegante e, acima de tudo, capaz de gerar um informe novo, com enorme probabilidade de sobreviver e ser aceito, tanto pela originalidade, quanto pela correção descritiva.

Vêm estes comentários a propósito do texto "Sete pecados fatais ao submeter um manuscrito para publicação" de autoria dos Editores do American Journal of Public Health, aparecido no no ${ }^{5}$, volume 84, de maio, de 1994, dessa revista.

Os editores enumeram, então, os sete pecados, como sendo:

Pecado 1: Oconteúdo do manuscrito não tem interesse direto paraa Saúde Pública (a revista em pautaé de interesse exclusivo para a Saúde Pública).

Pecado 2: O conteúdo do manuscrito não oferece nada de novo.

Pecado 3: O conteúdo do manuscrito revela uma seleção inadequada dos elementos do projeto de estudo (particularmente em estudos populacionais).

Pecado 5: O conteúdo do manuscrito oferece somente dados preliminares.

Pecado 6: O conteúdo do manuscrito deixa transparecer uma elaboração preliminar defeituosa.

Pecado 7: O conteúdo do manuscrito não passa de uma revisão da literatura.

Ao mencionar estes chamados sete pecados, os responsáveis pelo texto, a que chamam de "Anotação", não têm outra intenção que não seja facilitar a caminhada dos autores, com vistas à aceitação, para publicação no Americam Journal of Public Health. dos resultados de seus estudos. E assim fazem sugestões aos autores para que não se deixem cair na tentação pecaminosa, dando-lhes, noentanto, a oportunidade de "caso sintam que foram tratados com injustiça, que defendam seu trabalho, apresentando objeções lógicas" até porque os Editores não são infalíveis.

Trata-se de uma discussão cuja leitura é de particular interesse e grande oportunidade, até pelo quanto pode generalizar-se a outras revistas científicas que desejem merecer a confiança de seus leitores, com vistas a obter a informação que sirva de sólido amparo ao aprimoramento de conhecimentos, mesmo ao simples desenvolvimento da curiosidade intelectual.

José Alberto Neves Candeias

Editor Associado 